U.S. National Institutes of Health $(G M-08217)$ and the National Science Foundation ( $(Y 14240)$.

${ }^{2}$ Ropartz, C., Lenoir, R., and Rivat, L., Nature, 189, 586 (1961).

${ }_{2}^{2}$ Edelman, G. M., and Benacerraf, B., Proc. U.S. Nat. Acad. Sci., 48, 1035 (1962).

${ }^{3}$ Cohen, S., Nature, 197, 253 (1963).

- Fudenberg, H., and Franklin, E. C., Ann. Intern. Med., 58, 171 (1963).

${ }^{5}$ Grubb, R., Acta Path. Microbiol. Scand, 39, 195 (1956).

${ }^{6}$ Grubb, R., and Laurell, A. B., Acta P'ath. Microbiol. Scand., 39, 390 (1956).

'Poulik, M. D., and Edelman, G. M., Nature, 191, 1274 (1961). ${ }^{8}$ Edelman, G. M., Benacerraf, B., Ovary, Z., and Poulik, M. D., Proc.
U.S. Nat. Acad. Sci., 47, 1751 (1961).

${ }^{9}$ Edelman, G. M., and Gally, J. A., J. Kxp. Med., 116, 207 (1962).

${ }^{10}$ Berggard, I., and EdeIman, G. M., Proc. U.S. Nat. Acad. Sci., 49, 330 (1963).

1 Remington, J. S., Marier, E., Lerner, A. M., Gitlin, G., and Finland, M. Nature, 184,407 (1962).

12 Putnam, F. W., The Plasma Proteins, 2, edit. by Putnam, F. W., 345 (Academic P'ress, New York, 1960).

${ }^{13}$ Korngold, L., and Lipari, R., Cancer, 8, 262 (1956).

"Mannik, M., and Kunkel, H. G., J. Exp. Med., 116, 859 (1962)

${ }^{15}$ Migita, S., and Putnam, F. W., J. Exp. Med.,117, 81 (1963).

${ }_{16}$ Putnam, F. W., and Miyake, A., J. Biol. Chem., 227, 1083 (1957).

27 Franklin, E. C., Fudenberg, H., Meltzer, M., and Stanworth, D. R., Proc. U.S. Nat, Acad. Sci., 48, 914 (1962)

${ }^{28}$ Harboe, M., Osterland, C. K., Mannik, M., and Kunkel, H. G., J. Exp. Med., 116, 719 (1962).

${ }^{19}$ Putnam, F. W., Biochim. Biophys. Acta, 63, 539 (1962).

${ }^{20}$ Putnam, F. W., Migita, S., and Easley, C. W., Protides of the Biological Fluils, edit. by Peeters, H., 10, 93 (ilsevier, Amsterdam, 1963).
${ }^{21}$ Anfinsen, C. B., Haber, E., Sela, M., and White, H. H., jun., Proc. U.S. Nat. Acad. Sci., 47, 1309 (1961).

${ }^{22}$ Levinthal, C., Signer, E. R., and Fetherolf, K., Proe. U.S. Nat. A cad. Sci., 48, 1230 (1982).

${ }^{23}$ Smithies, O. (unpublished results).

${ }^{24}$ Uhr, J. W., and Finkelstein, M. S., J. Exp. Med., 117, 457 (1963).

${ }^{25}$ Smithies, O., Connell, G. E., and Dixon, G. H., Nature, 196, 232 (1962).

${ }^{26}$ Baglioni, C., Proc. U.S. Nat. Acad. Sci., 48, 1880 (1962).

${ }^{27}$ Nance, W. E., Science, 141, 123 (1963).

${ }^{2 y}$ Crick, F. H., Barnett, L., Brenner, S., and Watts-Tobin, R. J., Nature, 192, 1227 (1961).

${ }^{29}$ Benzer, S., and Champe, S. P., Proc. U.S. Nat. Acad. Sci., 48, 1114 (1962). ${ }^{30}$ Taylor, J. H., Woods, P. S., and Hughes, W. L., Proc. U.S. Nat. Acad.

${ }^{31}$ Taylor, J. H., Genetics, 43, 515 (1958).

${ }^{32}$ Schwartz, D., Genetics, 38, 251 (1953).

${ }^{33}$ Laughnan, J. R., Proc. Symp. Mutation and Plant Breeding, NAS-NRC $981,3(1961)$.

${ }^{34}$ Wood, W. B., and Berg, P., Proc. U.S. Nat. Acad. Sci., 48, 94 (1962)

${ }^{35}$ Bautz, E. K. F., Proc. V.S. Nat. Acad. Sei., 49, 68 (1963).

${ }^{36}$ Nirenberg, M. W., and Matthaci, Proc. U.S. Nat. Acad. Sci., 47, 1586 (1961).

${ }^{37}$ Lengyel, P., Speyer, J. F., and Ochod, S., Proc. U.S. Nat. Acad. Sci. . 47. 1936 (1961)

"18 Nirenberg, M. W., Sci. Amer, 208, 80 (1963)

${ }^{38}$ Jukes, T. H., Proc. U.S. Nat. Acad. Sci., 48, 1809 (1962),

40 Spencer, M., Fuller, W., Wilkins, M. H. F., and Brown, G. L., Nature, 194, $1014(1962)$

${ }^{41}$ Goodman, H. M., and Rich, A., Proc. U.S. Nat, Acad. Sci., 48, 2101 (1962).

${ }^{42}$ Porter, R. R., McFadden, M. L., and Smith, E. I., J. Biol. Chem., 214, $185(1955)$.

\title{
OBITUARY
}

\section{Prof. B. B. Bevan-Baker}

BEVAN-BAKER, who died on July 1 at the age of seventy three, was a man of rich and varied talents whose early promise of the highest scientific and mathematical achivement was tragically frustrated by the ill-health that beset him from middle life. But until illness enforced an early retirement, he gave distinguished service to the University of London and Proyal Holloway College.

Bevan Braithwaite Baker was born in 1890; in ultim. ately adopting the surname Bevan-Baker he was merely acquiescing in a usage of many of his friends. He entered University College, London, in 1906 and graduated in physics at the age of nineteen. He then did research on crystal structure in metals in London and in Munich; in some of this work he was associated with his contemporary, E. N. da C. Andrade (now Professor), to whom he evidently owed his introduction to tho subjoct. Baker's interests then changed and he took London degrees in mathematics in 1912 and 1914. During the First World War he served with the Friends' Ambulance Unit in Italy, this being in accordance with his Quaker upbringing. On his return, he was from 1918 until 1920 assistant in pur $\theta$ mathematics in University College. From 1920 until 1924, Baker was lecturer in mathematics in Edinburgh under E. T. Whittaker. This was the time of his fruitful mathematical activity. His main work was a series of papers on periodic orbits, but he wrote also on such varied topics as the hypergeometric function, the path of an electron in the neighbourhood of an atom, and an extension of Heaviside's operational calculus. Baker was elected a Fellow of the Royal Society of Edinburgh in 1921; he gained a D.Sc. at Edinburgh in 1923 for a much extended account of his dynamical work. He was secretary of the Edinburgh Mathematical Society from 1921 until 1924

From 1924 until 1944, Baker was professor of mathematics in the University of London and head of the Department of Mathematics in Royal Holloway College. He played a big part in the general affairs of the College in peace and in war. He was called on to serve for two consecutive three-year terms as a Staff Governor, a most exceptional procedure. During his headship, the undergraduate school of mathematics flourished greatly and its students gained more than a proportionate share of high honours in University of London examinations. A few of these women mathematicians began postgraduate work at Royal Holloway College before going on to research elsewhere, and they now hold distinguished positions in universities in Britain and overseas. Although Baker was disappointed at not doing more to develop a postgraduate school, this was actually the beginning of what has now become a well-known research centre (now taking both men and women students). But no account of Baker's time at Royal Holloway College should omit mention of Miss Marion Pick, a graduate of the College and a lecturer throughout Baker's term of office, who supplied the immediate stimulus to the students who were to make a career in mathematies and who also kept the Department in full operation during Baker's illnesses.

Baker was the most unselfish of men and bestowed innumerable kindnesses on colleagues and students. At one time he was an impressive figure of immense girth. This was because of thyroid trouble and after this was cured he became over-slim. During the rest of his working life he had a series of illnesses until his doctors ordered his retirement at the early age of fifty-four. Baker was denied the stamina to do much research work after joining Royal Holloway College. His name appears as joint author with E. T. Copson of The Mathematical Theory of Huygens' Principle (Oxford, 1939), but again his health eaused his contribution to be far less than ho wished.

Music was Baker's ruling passion; he was a pianist of the highest class for a non-professional, and he played various other instruments and took part in oporatic and other singing. Family opinion in his youth had dissuaded Baker from following music as a profession, so it was a wonderful consolation for him for many years to share in and to enrich the musical life of Royal Holloway College. In 1918 Baker married Margaret Barbour of Edinburgh, sister of the distinguished geologist, G. B. Barbour of Cincinnati. She sustained him in every way until her death in 1961. Until then he had enjoyed his retirement in improved health but his health declined again after that. Baker is survived by four of his five children.

W. H. McCrea 